\title{
Linear and non-linear functions of volume index to estimate woody biomass in high density young poplar stands
}

\author{
JY Pontailler ${ }^{1 *}$, R Ceulemans ${ }^{2}$, J Guittet ${ }^{1}, \mathrm{~F} \mathrm{Mau}^{2}$ \\ 'Laboratoire d'écophvsiologie végétale (CNRS Ura 2154), bâtiment 362, \\ université Paris-XI, 91405 Orsay cedex, France \\ ${ }^{2}$ Department of Biology. University of Antwerpen (UIA), Universiteitsplein I. \\ B-2610 Wilrijk, Belgium
}

(Received 3 April 1996; accepted 9 January 1997)

\begin{abstract}
Summary - Biomass estimations are very important in short rotation high density stands, but usually require some destructive sampling. This paper discusses the potential use of allometric relationships based on volume index (height $\times$ diameter squared) for accurate and non-destructive estimations of stem biomass. When using this approach, one implicitly assumes a constant conversion factor from stem volume index to real stem volume as well as a constant wood infradensity (stem dry mass versus fresh volume), both assumptions being questionable. Our results on five different poplar clones grown at two different sites (Afsnee, near Gent, Belgium and Orsay, near Paris, France) and under two different cultural management regimes underscore the following points: i) stem diameter measured at $22 \mathrm{~cm}$ aboveground and in two perpendicular directions is a relevant parameter to compute volume index in high density poplar stands; ii) power function regression equations fit the stem volume index versus stem dry mass relationship better than simple linear regressions; iii) attention should be paid to variation in wood infradensity, which ranged from 0.35 to $0.44 \mathrm{~kg} \mathrm{dm}^{-3}$ in our study.
\end{abstract}

short rotation forestry / high density plantations / Populus / volume index / allometric relationships

Résumé - Fonctions linéaires et non linéaires de l'indice de volume pour l'estimation de la biomasse sèche de jeunes plantations de peupliers. L'estimation de la biomasse sur pied de parcelles denses cultivées en courtes rotations est généralement indispensable mais requiert le plus souvent des techniques destructives lourdes. Cet article discute de l'utilisation potentielle des relations allométriques utilisant l'indice de volume (hauteur du brin $\times$ carré de son diamètre à la base) pour l'estimation précise de la biomasse sèche de jeunes tiges de peuplier. Par ce type d'approche, on suppose impli-

* Correspondence and reprints

Tel: (33) 01691571 37; fax: (33) 01691572 38; courriel: jean-yves.pontailler@eco.u.psud.fr 
citement qu'il existe un facteur de conversion constant entre volume vrai et indice de volume, et que l'infradensité du bois est constante. Ces deux hypothèses sont loin d'être rigoureusement vérifiées. Les résultats présentés ici portent sur cinq clones de peupliers cultivés sur deux sites (Afsnee, près de Gand en Belgique et Orsay, près de Paris) selon deux techniques culturales différentes. Ils mettent en évidence les points suivants : i) le diamètre de la tige, mesuré à la hauteur de $22 \mathrm{~cm}$ selon deux directions perpendiculaires, est un paramètre pertinent pour le calcul de l'indice de volume de jeunes brins de peupliers ; ii) les tarifs utilisant une fonction puissance de l'indice de volume fournissent des estimations plus précises de la masse sèche des brins que ne le font les tarifs linéaires ; iii) les variations de l'infradensité du bois (ici de 0,35 à $0,44 \mathrm{~kg} \mathrm{dm}^{-3}$ ) peuvent réduire considérablement la précision de ces estimations.

\section{indice de volume / allométrie / Populus / sylviculture en courte rotation}

\section{INTRODUCTION}

Within the frame work of the search for alternative, renewable energy sources, short rotation woody crops play an important role. Moreover, a renewed interest in these biomass production systems has recently arisen since they do not consume fossil energy sources, and thus are neutral with regard to the atmospheric $\mathrm{CO}_{2}$ balance (Ranney et al, 1991).

Within the interest of land set aside programmes in industrialized countries, a joint European research program was initiated as a collaborative study between the Universities of Antwerpen, Edinburgh and ParisSud. The overall aim of this project was to explain the production differences observed among different poplar clones in terms of physiological processes to identify early selection criteria. This work supplies a useful tool to these types of studies. The field observations were made over 3 years on five poplar clones grown at two experimental sites (Afsnce, Belgium and Orsay, France).

More than other genera, Populus has proved to be extremely well suited for biomass production, because of its high photosynthetic capacity and its superior growth performance (Barigah el al, 1994). Much variation exists among different poplar clones in growth and production aspects (Heilman and Stettler, 1985: Ceulemans, 1990). To date, many experimental trials with various poplar materials have investi- gated the potentials to better capture the clonal differences in the production performance. These trials frequently use nondestructive methods to estimate biomass production.

Forest managers are often faced with several estimates of plantation productivity. Not only are there different measures of productivity, such as site index, annual volume increment or standing volume at some fixed age. but all of them may be obtained from different sources. A rather cumbersome technique of assessing alternalive estimates of volume increment in the absence of true observations has been proposed by Reed and Jones (1989).

Most biomass studies at stand level utilize one of the frequently used methods: the 'mean tree', regression analysis or unit area, with the regression techniques being the most commonly used (Verwijst. 1991). The dependent variable (dry weight or biomass) is expressed as a function of an independent, easily measurable variable such as diameter at breast height (DBH), or height or a combination of both $\left(H \cdot D^{2}\right)$. In young stands, DBH (at $1.30 \mathrm{~m}$ ) is not a pertinent parameter because of the small tree size. On the other hand, problems arise when measuring diameter close to the ground because stems often widen at that level.

In most cases, one assumes that wood biomass is proportional to $\mathrm{H} \cdot \mathrm{D}^{2}$ in a simple lincar model passing through the origin. 
When taking a destructive subsample and performing an allometric regression analysis, the result is a linear regression that docs not pass through the origin and that is only valid for a narrow range of tree sizes (Verwijst, 1991).

The objectives of this paper are i) to illustrate the limits of the linear model, ii) to evaluate power function equations for predicting biomass, iii) to examine their respective predictive power for large and small tree sizes and iv) to underscore the role of the variation in wood infradensity (wood dry mass versus wood fresh volume), which is frequently neglected but might introduce another substantial uncertainty.

\section{MATERIALS AND METHODS}

\section{Plant materials}

Five poplar ( $P$ opululus) clones were used in this study. These included two fast growing, interspecific (Populus trichocarpa $\times P$ deltoides) hybrid clones (Beaupré and Raspalje), two native American $P$ trichocarpa clones (Columbia River and Fritzi Pauley) and one Euramerican reference clone $(P$ deltoides $\times P$ nigra, cultivalr Robusta). These five clones differ in growth ratte, in foliage structure. in gas exchange metabolism and in phenology (Maul and Impens. 1989; Ceulemans et al, 1993; Barigah et al. 1994). Details about origin, parentage, sex and productivity of these clones have been described elsewhere (Ceulemans, 1990). All plants at both sites were grown from homogeneous, hardwood cuttings obtained from the Belgian Government Poplar Research Station (Gerairdsbergen, Belgium).

\section{Plantation design}

Cuttings of the five clones were planted in April 1987 in clonal blocks of a $0.8 \mathrm{~m} \times 0.8 \mathrm{~m}$ pattern (ie, a density of 15625 trees per ha) in Afsnee (near Gent, Belgium; $51^{\circ} 03^{\circ} \mathrm{N}, 03^{\circ} 39^{\circ} \mathrm{E}$ ) and in Orsay (near Paris, France; $48^{\circ} 50^{\circ} \mathrm{N} .02^{\circ} 20^{\circ} \mathrm{E}$ ). Each homogeneous block $(9 \times 9$ trees in Afsnee and $5 \times 5$ trees in Orsay) was surrounded by an unplanted row of $1.6 \mathrm{~m}$ width, and only a weak border effect on height and volume growth was observed (Van Hecke et al, 1995). A drip irrigation system was installed and irrigation was applied during the entire duration of the experiment. Mechanical weed control was only necessary during the establishment year; in Afsnee also some herbicides were applied. In Afsnee, 5 tonnes of manure were applied during the first year (1987) and two additional (total) fertilizer applications were given in May and July 1988. In Orsay. $100 \mathrm{~kg}$-ha of total fertilizer $(\mathrm{N}, \mathrm{P}, \mathrm{K})$ were applied twice every year, in April and July.

In Afsnee, an additional 27 cuttings per clone were planted at the same density next to the experimental plots to allow destructive sampling after the first growing sealson. The experimental plots were only harvested after the third year. In contrast, a coppice system was applied in Orsiay: at the end of the first growing season (1987), all stems were harvested for measurements of biomass production (stem + branches). In early 1988, cut stumps resprouted (yielding between three and eight stems per stump) and grew for 2 more consecutive years until harvest at the end of 1989.

\section{Measurements}

Destructive measurements were performed at both sites after the first year (winter 1987-1988). Ten center trees were harvested in Afsnee compared with all 25 in Orsay. At the end of the following year (1988) five trees per clone were harvested in Afsnce. Finally, after the third year, all trees were harvested at both sites (coppiced in Orsay and final harvest in Afsnee). Stem dry mass (DM) was determined after drying at $80^{\circ} \mathrm{C}$ until constant mass (branches are not considered in the present study).

At the end of the first growing season, stem diameter (D) was meastured at $22 \mathrm{~cm}$ above ground in two perpendicular directions with a dial caliper (at $0.1 \mathrm{~mm}$ resolution). In Orsay, D was also measured at $10 \mathrm{~cm}$ and at mid-height, and at 2()-cm intervals on a subsample of four trees to examine taper. Total plant height $(\mathrm{H})$ was measured to the nearest $0.5 \mathrm{~cm}$ with an aluminium levelling rod.

At the end of the second year (in Afsnee only), stem diameters were measured (in two directions) at $0.5 \mathrm{~m}$ intervals on all harvested plants (five per clone). For each individual $0.5 \mathrm{~m}$ stem segment, the volume was calculated using the 
formula for a truncated cone (see later). Stem real volume $(V)$ per plant was then obtained by summing volumes of all individual stem segments (Causton, 1985; Kozak, 1988).

At the end of the third year (in Orsay only), all these measurements were performed on all trees. In addition, wood infradensity (ie, DM/V ratio) was determined from real stem volume data using the water displacement technique.

Stem volume index was calculated as $\mathrm{H} \cdot \mathrm{D}^{2}$, with $\mathrm{H}=$ stem height and $\mathrm{D}=$ stem diameter at $22 \mathrm{~cm}$ aboveground, unless indicated otherwise. A general model was tested,

$$
\mathrm{DM}=\beta \mathrm{VI} \gamma+\alpha
$$

where DM is dry mass and VI is volume index together with two reduced forms, a linear model $(\gamma=1)$ and a power model $(\alpha=0)$. The regression parameters were estimated by using an iterative method (SigmaPlot software). The two reduced forms were compared to the general model by using $F$-tests. To test statistical differences among clones, $F$-tests have also been used.

\section{RESULTS AND DISCUSSION}

\section{Basic considerations}

As a first approximation, a stem can be considered as a geometrical cone, while $\mathrm{H} \cdot \mathrm{D}^{2}$ is a larger rectangular parallelepiped:

$$
\begin{gathered}
\text { Stem volume }(\mathrm{V})=1 / 3\left(\mathrm{H} \cdot \pi \cdot \mathrm{D}^{2}\right) / 4 \\
=0.2618 \mathrm{H} \cdot \mathrm{D}^{2}
\end{gathered}
$$

where 0.2618 is a constant factor and $\mathrm{V}$ and $\mathrm{H} \cdot \mathrm{D}^{2}$ are expressed in $\mathrm{dm}^{3}$.

More precisely, the stem shape is closer to a truncated cone with volume:

$$
V=(H \cdot \pi) \cdot\left(D^{2}+D \cdot d+d^{2}\right) / 12
$$

where $\mathrm{D}$ is the diameter at the base, and $\mathrm{d}$ is the diameter at the top of the truncated cone.

Assuming a constant top stem diameter (d) of about $5 \mathrm{~mm}$, the volume of the truncated cone exceeds that of a cone of similar height and base, the difference between the two being smaller when tree size increases.
In our young plots, for that very reason, small stems exhibit a rather cylindrical shape while bigger ones are more conical. This makes the regression coefficient larger for small stems than for large ones. In these conditions, dry mass versus volume index curves exhibit a gentle curvature, this fact being in favour of a non-linear model.

The stem volume estimation is very dependent on the choice of the height at which stem basal diameter is measured. Figure 1 shows that the stem diameter largely increases when approaching the ground level. It is of course necessary to take these low plant parts into account when estimating the stem volume. However, putting the stem diameter measurement too low will result in a significant overestimation. As can be seen from figure 1 , the stem diameter measurement at $22 \mathrm{~cm}$, which was arbitrarily chosen for convenience in this study (see Ceulemans et al, 1993), seems to be a good compromise for assessing the volume of these young poplar stands.

\section{Volume index versus real volume}

It follows from the previous considerations on stem shape that there is an important difference between the real volume and the volume index. This is obvious from the difference between the $1 / 1$ line (dotted line) and the relationship obtained for 1 - and 2year-old stems shown in figure 2 (clone Raspalje). The relationship between real stem volume and stem volume index is linear and highly significant $\left(r^{2}=0.992\right)$, but the experimentally observed regression coefficient $(0.2893)$ differs slightly from the theoretically calculated one $(0.2618)$. Other clones (not shown) show a similar trend. However, the positioning of the data points suggests that there is a slight deviation from linearity towards high values, which is due to the shift from a cylindrical shape to a rather conical one when stem size increases. 


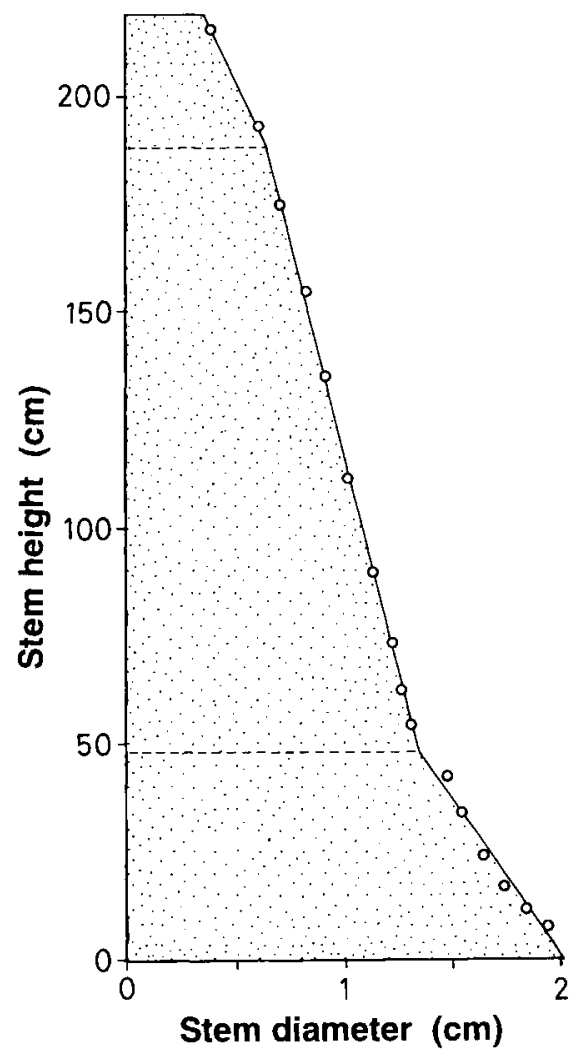

Fig 1. Graphical representation of the tapering of a 1-year-old poplar (clone Columbia River) at the end of the growing season. Total plant height was $219 \mathrm{~cm}$.

\section{Wood infradensity}

In a direct stem volume index to dry mass conversion, the wood infradensity (stem dry mass versus fresh volume) is implicitly taken into account as a constant factor. However, important variations among clones and within trees of the same clone have been shown (Schalck et al, 1978).

After the first growing season (1987) stem wood infradensity ranged from $0.441 \mathrm{~kg} \mathrm{dm}^{-3}$ for clone Beaupré to $0.482 \mathrm{~kg} \mathrm{dm}^{-3}$ for clone Raspalje. Except for the differences between these two clones, clonal differences in density of the first year stem wood were not significant $(P=0.05)$.

After the second growing season, no signilicant difference in stem wood density was observed among the five clones, nor between the two sites (table I). However, wood density did significantly differ between different height growth increments (HGI) on trees of the same age. According to Bormann (1990), the relative proportion of sapwood and heartwood has to be considered in models predicting biomass (see also Snell and Brown, 1978). In the present study, all young stems are sapwood only but differences are observed between the 1and 2-year-old density values (table I). Attention must be paid to this when extrap-

Table I. Stem wood infradensity values (in $\mathrm{kg} \mathrm{dm}^{-3}$ ) for five poplar clones in Afsnee (five trees per clone) and Orsay (five to eight trees per clone).

\begin{tabular}{lccccc}
\hline & \multicolumn{2}{c}{ Orsay } & & \multicolumn{2}{c}{ Afsnee } \\
\cline { 2 - 3 } Clone & l-year-old & 2-year-old & & l-year-old & 2-year-old \\
\hline Beaupré & $0.398(0.023)$ & $0.396(0.014)$ & & $0.399(0.026)$ & $0.369(0.039)$ \\
Columbia River & $0.406(0.030)$ & $0.443(0.020)$ & & $0.347(0.017)$ & $0.358(0.038)$ \\
Fritzi Pauley & $0.385(0.027)$ & $0.432(0.024)$ & & $0.391(0.022)$ & $0.367(0.029)$ \\
Raspalje & $0.413(0.016)$ & $0.392(0.017)$ & & $0.423(0.034)$ & $0.409(0.040)$ \\
Robusta & $0.402(0.028)$ & $0.423(0.020)$ & & - & $0.408(0.018)$ \\
\hline
\end{tabular}

Mean values and standard deviation (in parentheses) of 1- and 2-year-old wood from 2-year-old trees are presented. 


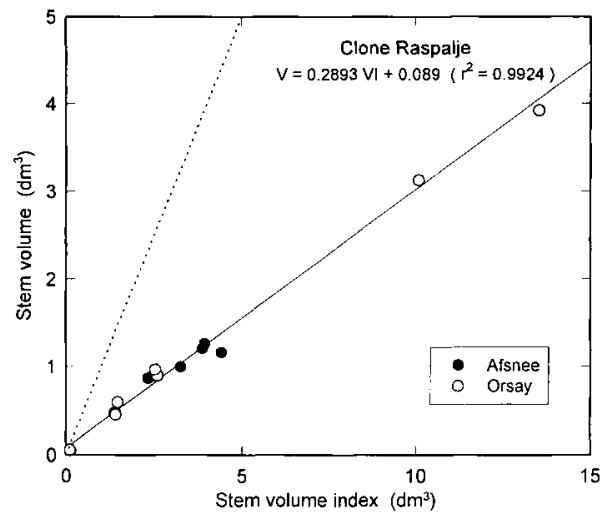

Fig 2. Relationship between stem volume index and real stem volume for poplar clone Raspalje at two different experimental sites (Afsnee and Orsay). Values for 1- and 2-year-old stems are shown together. The dashed line represents the $1 / 1$ line.

olating allometric relationships as soon as the age of the stems differs.

\section{Volume index versus dry mass}

The estimation of stem dry mass by means of volume index data integrates incertainties due to both real volume estimation and assumptions on wood density. Stem volume index estimations based on diameter measurements at $10 \mathrm{~cm}$ aboveground, at $22 \mathrm{~cm}$ aboveground and at mid-height were compared for the five clones in Orsay (1987). Except for one clone (Robusta), the best fit between volume index and dry mass was obtained with stem diameter measured at $22 \mathrm{~cm}$ (table II). This might be explained by the fact that stem diameter at $10 \mathrm{~cm}$ aboveground is strongly influenced by the basal swelling (see fig 1), which varies from one stem to another. Measurements at midplant height are less accurate since the diameter is much smaller, thus causing a relatively larger measuring error. In addition, little information is given on the lower portion of the stem where most of the biomass is concentrated. Therefore, all estimations used further in this text are based on stem diameters measured at $22 \mathrm{~cm}$ aboveground.

In other respects, all stem diameters were measured in two perpendicular directions (d1 and d2) since a stem cross-section is not always perfectly circular. Then, volume index calculation is more accurate when using the product $\mathrm{d} / \cdot \mathrm{d} 2$ rather than $[(\mathrm{d} 1+\mathrm{d} 2) / 2]^{2}$ (ellipse versus circle), but the difference is often negligible in practice: when comparing these two approaches on a sample of 732 -year-old stems of all

Table II. Coefficients of determination $\left(r^{2}\right)$ of linear regression equations between stem volume index and stem dry mass for five different poplar clones grown in Orsay and determined after the first growing season.

\begin{tabular}{lccc} 
Clone & Diameter at $10 \mathrm{~cm}$ & Diameter at $22 \mathrm{~cm}$ & Diameter at mid-height \\
\hline Beaupré & 0.9733 & 0.9833 & 0.9419 \\
Columbia River & 0.9807 & 0.9824 & 0.9765 \\
Fritzi Pauley & 0.9861 & 0.9875 & 0.9865 \\
Raspalje & 0.9729 & 0.9876 & 0.8264 \\
Robusta & 0.9127 & 0.9153 & 0.9448
\end{tabular}

Stem volume index was calculated using stem diameters at $10 \mathrm{~cm}$ aboveground, at $22 \mathrm{~cm}$ aboveground and at mid-plant height. 
clones, only two stems showed a discrepancy superior to $1 \%$ on volume index estimates.

\section{One-year-old stems (1987)}

Very significant correlations $(P=0.001)$ were observed between stem volume index and stem dry mass for all five clones at both sites. As an example, this relation is shown for clone Columbia River in figure 3 . Table III shows the global, linear and power regression equations with their respective determination coefficients. In all cases, the general model gives the best fit, but the power model shows quasi-similar performance. However, $F$-tests performed between

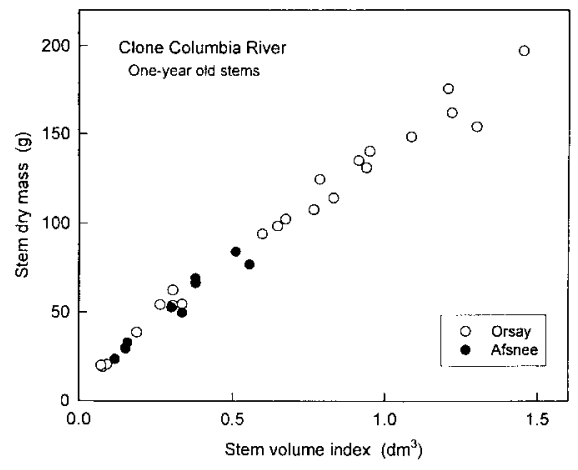

Fig 3. Relationship between volume index and dry mass of 1-year-old stems of poplar clone Columbia River at two different experimental sites, Afsnee and Orsay, under the same cultural management.

Table III. Global (DM $\left.=\beta V I^{\gamma}+\alpha\right)$, linear and power regression equations for the allometric relationship between dry weight $(\mathrm{DM}, \mathrm{g})$ and stem volume index $\left(\mathrm{VI}, \mathrm{dm}^{3}\right)$ of five different poplar clones established after the first growing season (1987) in Afsnee (Belgium) and Orsay (France).

\begin{tabular}{|c|c|c|}
\hline Clone & Afsnee & Orsay \\
\hline \multirow[t]{2}{*}{ Beaupré } & $\begin{array}{l}\mathrm{DM}=145.2 \mathrm{VI}^{0.652}-8.6(0.985) \\
\mathrm{DM}=116.7 \mathrm{VI}+23.5(0.983)\end{array}$ & $\begin{array}{l}\mathrm{DM}=169.7 \mathrm{VI}^{0.784}-15.1(0.985) \\
\mathrm{DM}=118.0 \mathrm{VI}+39.1(0.983)\end{array}$ \\
\hline & $\mathrm{DM}=137.2 \mathrm{VI}^{0.718} \quad(0.985)$ & $\mathrm{DM}=155.3 \mathrm{VI}^{0.833} \quad(0.985)$ \\
\hline \multirow[t]{2}{*}{ Columbia River } & $\begin{array}{l}\mathrm{DM}=146.6 \mathrm{VI}^{(0.499}-26.8(0.957) \\
\mathrm{DM}=1.35 .3 \mathrm{VI}+10.3(0.947)\end{array}$ & $\begin{array}{l}\mathrm{DM}=137.4 \mathrm{VI}^{0.808}+3.0(0.985) \\
\mathrm{DM}=123.0 \mathrm{VI}+16.6(0.983)\end{array}$ \\
\hline & $\mathrm{DM}=132.2 \mathrm{VI}^{0.773}(0.954)$ & $\mathrm{DM}=140.6 \mathrm{VI}^{0.779} \quad(0.985)$ \\
\hline \multirow[t]{2}{*}{ Fritzi Pauley } & $\begin{array}{l}\mathrm{DM}=143.6 \mathrm{VI}^{1.224}+21.6(0.898) \\
\mathrm{DM}=138.8 \mathrm{VI}+13.0(0.897)\end{array}$ & $\begin{array}{l}\mathrm{DM}=148.6 \mathrm{VI}^{0.775}-1.7(0.992) \\
\mathrm{DM}=1.33 .3 \mathrm{VI}+16.0(0.987)\end{array}$ \\
\hline & $\mathrm{DM}=141.6 \mathrm{VI}^{(0.787}(0.895)$ & $\mathrm{DM}=147.1 \mathrm{VI}^{0.791} \quad(0.992)$ \\
\hline \multirow[t]{2}{*}{ Raspalje } & $\begin{array}{l}\mathrm{DM}=593.0 \mathrm{VI}^{0.151}-449.1(0.897) \\
\mathrm{DM}=114.7 \mathrm{VI}+.30 .5(0.882)\end{array}$ & $\begin{array}{l}\mathrm{DM}=162.2 \mathrm{VI}^{(0.797}+0.6(0.989) \\
\mathrm{DM}=116.9 \mathrm{VI}+46.7(0.987)\end{array}$ \\
\hline & $\mathrm{DM}=144.7 \mathrm{VI}^{(0.732}(0.890)$ & $\mathrm{DM}=162.9 \mathrm{VI}^{0.795}(0.989)$ \\
\hline \multirow[t]{2}{*}{ Robusta } & $\begin{array}{l}\mathrm{DM}=128.3 \mathrm{VI}^{0.515}-18.1(0.970) \\
\mathrm{DM}=141.8 \mathrm{VI}+8.4(0.960)\end{array}$ & $\begin{array}{l}\mathrm{DM}=124.0) \mathrm{VI}^{0.532}-11.5(0.927) \\
\mathrm{DM}=104.2 \mathrm{VI}+21.8(0.915)\end{array}$ \\
\hline & $\mathrm{DM}=127.5 \mathrm{VI}^{0.763} \quad(0.967)$ & $\mathrm{DM}=115.0 \mathrm{VI}^{0.633} \quad(0.926)$ \\
\hline
\end{tabular}

Regressions were based on ten trees in Afsnee and 23-25 trees in Orsay. Values in parentheses are coefficients of determination $\left(r^{2}\right)$. 
the global model and the two reduced forms were not significant $(P>0.05)$. It can be noted that, in the linear model, the order of magnitude of the intercept is 8 to $46 \mathrm{~g}$. This results in a poor estimation of the mass of small stems. The global model shows quite moderate intercepts ( -27 to $22 \mathrm{~g}$ ) except clone Raspalje in Afsnee. The reduced number and range of the data from Afsnee causes a large variation in the regression coefficients of the global model, leading to unrealistic functions, valid over a narrow size range only. The fact that a power function has to pass through the origin largely reduces this variability and probably insures a better accuracy of the power model in the estimation of the biomass of small stems. This is relatively important in coppices where small stems are numerous and represent a nonnegligible part of the total biomass.

In spite of the fact that in 1987 all clones were managed in the same way at both sites, differences in their regression coefficients were observed. It is therefore important to pay attention to this between-clone variability when extrapolating general allometric relations. Differences in regression coefficients between the two sites were rather small.

\section{Two-year-old stems}

Data from Afsnee (1988) are compared to those of Orsay (1989) as the stand in Orsay was coppiced during the winter 1987-1988 (both plots being 2-year-old aboveground). Since there was little difference between the allometric relationships from Afsnee and Orsay in the first year, we established the relationship between volume index and stem dry mass on the combined data of Afsnee (1988) and Orsay (1989). For all clones, the data points from Afsnee fell right within the range of those of Orsay (see fig 4, example clone Fritzi Pauley). Although all regression equations yielded highly significant correlations $(P=0.001)$, the best fit was obtained using either global or power models (table IV).

$F$-tests on the sums of squares of residuals were used for model comparison (table V). When comparing the best fit global model to the linear model, it appeared that they differed significantly for two of five clones. When the power model was compared to the global one, no difference was observed. Therefore, we can first reject the linear model. This was confirmed by observing the residuals (an example is shown fig 5 for clone Fritzi-Pauley): their distribution, biased in the linear model, was more satisfactory in the two other models.

A choice must still be made between the two other models (global and power) that do not significantly differ. Our preference goes to the power function since it has fewer parameters, but also because it passes through the origin. This implicitly supplies additional information that should be taken into account, especially when the sample has a narrow range.

Among-clone variation in regression coefficients was lower for the 2-year-old stems than for the 1-year-old stems, which

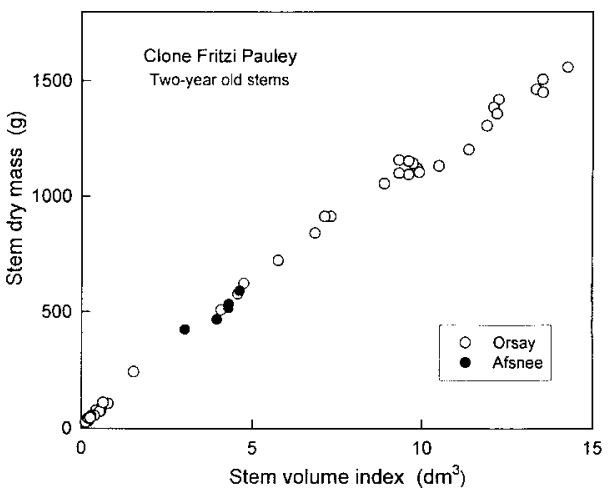

Fig 4. Relationship between volume index and dry mass of 2-year-old poplar clone Fritzi Pauley at two different experimental sites, Afsnee (noncoppiced) and Orsay (coppiced). 
Table IV. Global $\left(\mathrm{DM}=\beta \mathrm{VI}^{\gamma}+\alpha\right)$, linear and power regression equations for the allometric relationship between dry mass (DM, g) and stem volume index $\left(\mathrm{VI}, \mathrm{dm}^{3}\right)$ of five different poplar clones grown in Afsnee (Belgium) and Orsay (France).

\begin{tabular}{|c|c|c|}
\hline Clone & Afsnee + Orsay & \\
\hline \multirow[t]{3}{*}{ Beaupré } & $\mathrm{DM}=176.0 \mathrm{VI}^{0.837}-18.1$ & $(0.985)$ \\
\hline & $\mathrm{DM}=103.6 \mathrm{VI}+88.6$ & $(0.982)$ \\
\hline & $\mathrm{DM}=166.0 \mathrm{VI}^{0.854}$ & $(0.985)$ \\
\hline \multirow[t]{3}{*}{ Columbia River } & $\mathrm{DM}=134.8 \mathrm{VI}^{0.905}+15.4$ & $(0.993)$ \\
\hline & $\mathrm{DM}=108.4 \mathrm{VI}+38.2$ & $(0.991)$ \\
\hline & $\mathrm{DM}=148.2 \mathrm{VI}^{0.868}$ & $(0.993)$ \\
\hline \multirow[t]{3}{*}{ Fritzi Pauley } & $\mathrm{DM}=164.6 \mathrm{VI} \mathrm{I}^{0.848}-10.2$ & $(0.997)$ \\
\hline & $\mathrm{DM}=109.8 \mathrm{VI}+42.8$ & $(0.994)$ \\
\hline & $\mathrm{DM}=157.6 \mathrm{VI}^{(0.863}$ & $(0.997)$ \\
\hline \multirow[t]{3}{*}{ Raspalje } & $\mathrm{DM}=157.9 \mathrm{VI}^{0.894}+5.5$ & $(0.994)$ \\
\hline & $\mathrm{DM}=115.3 \mathrm{VI}+57.5$ & $(0.992)$ \\
\hline & $\mathrm{DM}=161.5 \mathrm{VI}^{0.887}$ & $(0.994)$ \\
\hline \multirow[t]{3}{*}{ Robusta } & $\mathrm{DM}=160.4 \mathrm{VI}^{0.842}+1.7$ & $(0.991)$ \\
\hline & $\mathrm{DM}=114.8 \mathrm{VI}+40.9$ & $(0.985)$ \\
\hline & $\mathrm{DM}=162.0 \mathrm{VI}^{0.838}$ & $(0.991)$ \\
\hline
\end{tabular}

Data refer to 2-year-old stems. Regressions were based on more than 50 trees (five trees in Afsnee + $\approx 50$ trees in Orsay). Values in parentheses are coefficients of determination $\left(r^{2}\right)$.

might be explained by the much larger sample size and by their wider range. In Orsay, the coppice regime resulted in a wide variation of stem sizes, as can be seen in figure 4. To test the significance of the differences observed between clones, we computed a power regression on the data of all clones pooled together. We tested the fit of each clone separately to this general equation and compared this fit with the previously calculated fit to the equation from each respective clone, using F-tests. Three clones appeared distinct from the common pool: Columbia River, Fritzi Pauley and Raspalje.
In conclusion, in the framework of the present study, the power model gave better estimates of the biomass of the stems than the linear model. The linear model overestimated biomass on both ends of the regression line (ie, small and large stems) and underestimated the biomass of all stems of average size. It appears well adapted at plot level when considering a wide tree-size range only.

Allometric relationships may vary according to tree size and species. A variable allometric ratio model fitted to Populus tremuloides biomass data for bolewood, bolebark and current twig stem components 
Table V. Comparison of the global model with two reduced forms (linear [Lin] and power [Pwr]).

\begin{tabular}{lcccc}
\hline Clone & Lin/global & Pwr/global & F(0.05) & $d f$ \\
\hline Beaupré & 1.238 & 1.004 & 1.552 & 57 \\
Columbia river & 1.332 & 1.080 & 1.473 & 73 \\
Fritzi Pauley & 2.026 & 1.018 & 1.661 & 43 \\
Raspalje & 1.212 & 1.001 & 1.490 & 69 \\
Robusta & 1.632 & 1.001 & 1.490 & 69
\end{tabular}

Results of the $F$-test performed on the ratio of the sum of residual squares. df: degrees of freedom.

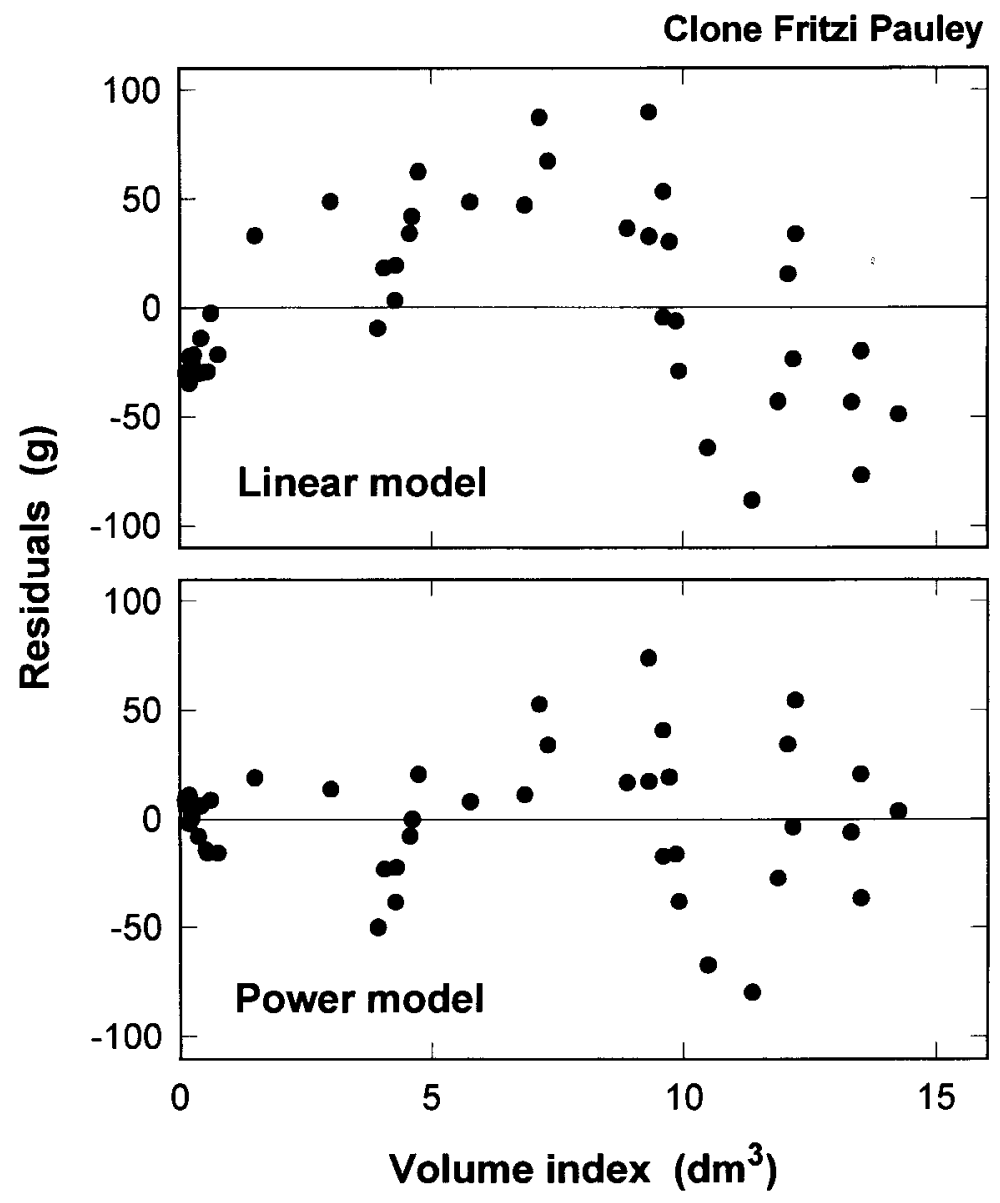

Fig 5. Residuals obtained when performing linear and power regressions. Clone Fritzi Pauley, 2year-old stems. 
was found to be superior to a power function or to a constant allometric ratio model (Ruark et al, 1987).

Observations made on rather small plots must be interpreted with caution because they may not always be extrapolated to larger acreages. For example, small plots may allow more side light penetration than would normally be expected. This may result in greater leaf retention, although this did not appear to be the case in our plots as most of the leaf area was in the uppermost portion of the crown where light was readily available (Ceulemans et al, 1993).

\section{ACKNOWLEDGEMENTS}

This research was financially supported by EC research contract EN3B-01 14-B/GDF within the Biomass R \& TD programme (second framework programme 1987-1989). The scientific exchange programme between the French CNRS and the Flemish Community (Themes 92.4, 92.7 and 93.1) greatly facilitated the fruitful collaboration between our two laboratories. Thanks to the reviewers who contributed to improve the treatment of our data. We acknowledge B Legay, $F$ Kockelbergh and TS Barigah for help with collecting the data, I Impens, M Mousseau, B Saugier, I Planchais and P Van Hecke for helpful discussions.

\section{REFERENCES}

Barigah TS, Saugier B, Mousseau M, Guittet J, Ceule mans R (1994) Photosynthesis, leaf area and productivity of five poplar clones during their establishment year. Ann Sci For 51, 613-625

Bormann BT (1990) Diameter-based biomass regression models ignore large sapwood-related variation in Sitka spruce. Can J For Res 20, 1098-1104

Causton DR (1985) Biometrical, structural and physiological relationships among tree parts. In: Attributes of Trees as Crop Plants (MGR Cannell, JE Jackson, eds), Titus Wilson \& Son, Huntingson, UK, 137-159
Ceulemans R (1990) Genetic Variation in Functional and Structural Productivity Determinants in Poplar. Thesis Publishers, Amsterdam, the Netherlands, $100 \mathrm{p}$

Ceulemans R, Pontailler JY, Mau F, Guittet J (1993). Leaf allometry in young poplar stands: reliability of leaf area index estimation, site and clone effects. Biomass Bioenergy 4, 315-321

Heilman PE, Stettler RF (1985) Genetic variation and productivity of Populus trichocarpa T \& G. and its hybrids. II. Biomass production in a 4-year plantation. Can J For Res 15, 384-388

Kozak A (1988) A variable-exponent taper equation. Can J For Res 18, 1363-1368

Madgwick HAI (1971) The accuracy and precision of estimates of the dry matter in stems, branches, and foliage in an old-field Pinus virginiana stand. In: Forest Biomass Studies, Univ Main Press, Orono, ME, USA, 105-112

Madgwick HAI (1983) Above-ground weight of forest plots - comparison of seven methods of estimation. NZ J For Sci 13, 100-107

Mau F, Impens I (1989) Comparative growth analysis of five first year establishment poplar clones (Populus sp) grown under a short-rotation intensive culture system. Ann Sci For 46, 250s-255s

Ranney JW, Wright LL, Mitchell CP (1991) Carbon storage and recycling in short-rotetion energy crops. In: Bioenergy and the Greenhouse Effect (CP Mitchell, ed), Nutek, Stockholm, 39-44

Reed DD. Jones EA (1989) Assessing multiple estimates of plantation productivity. Can J For Res $19,948-954$

Ruark GA, Martin GL, Bockheim JG (1987) Comparison of constant and variable allometric ratios for estimating Populus tremuloides biomass. For $S c t$ $33,294-300$

Schalck J, Lejeune J, Stevens M (1978) Density and Lignification of Woody Tissue from New Hybrids in a Poplar Ecosystem. FKFO report no 6, University of Gent, Belgium, $38 \mathrm{p}$

Snell JAK, Brown JK (1978) Comparison of tree biomass estimators - DBH and sapwood area. For Sci $24,455-457$

Van Hecke P, Moermans R, Mau F, Guittct J (1995) Border effects and size inequality in experimental even-aged stands of poplar clones (Populus). Ann Sci For 52, 193-200

Verwijst T (1991) Logarithmic transformations in biomass estimation procedures: violation of the linearity assumption in regression analysis. Biomass Bioenergy 1, 175-180 